\title{
Performance Improvement of Microcrystalline p-SiC/i-Si/n-Si Thin Film Solar Cells by Using Laser-Assisted Plasma Enhanced Chemical Vapor Deposition
}

\author{
Hsin-Ying Lee, ${ }^{1}$ Ting-Chun Wang, ${ }^{1}$ and Chun-Yen Tseng ${ }^{2}$ \\ ${ }^{1}$ Department of Photonics, Research Center Energy Technology and Strategy, Advanced Optoelectronic Technology Center, \\ National Cheng Kung University, Tainan 701, Taiwan \\ ${ }^{2}$ Institute of Microelectronics, Department of Electrical Engineering, Advanced Optoelectronic Technology Center, \\ National Cheng Kung University, Tainan 701, Taiwan
}

Correspondence should be addressed to Hsin-Ying Lee; hylee@ee.ncku.edu.tw

Received 20 February 2014; Accepted 26 April 2014; Published 14 May 2014

Academic Editor: Sudhakar Shet

Copyright (C) 2014 Hsin-Ying Lee et al. This is an open access article distributed under the Creative Commons Attribution License, which permits unrestricted use, distribution, and reproduction in any medium, provided the original work is properly cited.

The microcrystalline $\mathrm{p}-\mathrm{SiC} / \mathrm{i}-\mathrm{Si} / \mathrm{n}$-Si thin film solar cells treated with hydrogen plasma were fabricated at low temperature using a $\mathrm{CO}_{2}$ laser-assisted plasma enhanced chemical vapor deposition (LAPECVD) system. According to the micro-Raman results, the i-Si films shifted from $482 \mathrm{~cm}^{-1}$ to $512 \mathrm{~cm}^{-1}$ as the assisting laser power increased from $0 \mathrm{~W}$ to $80 \mathrm{~W}$, which indicated a gradual transformation from amorphous to crystalline Si. From X-ray diffraction (XRD) results, the microcrystalline i-Si films with (111), (220), and (311) diffraction were obtained. Compared with the Si-based thin film solar cells deposited without laser assistance, the short-circuit current density and the power conversion efficiency of the solar cells with assisting laser power of $80 \mathrm{~W}$ were improved from $14.38 \mathrm{~mA} / \mathrm{cm}^{2}$ to $18.16 \mathrm{~mA} / \mathrm{cm}^{2}$ and from $6.89 \%$ to $8.58 \%$, respectively.

\section{Introduction}

Recently, the silicon- (Si-) based thin film solar cells with several advantages, such as high absorptivity, easy fabrication, and low cost, have been extensively studied [1, 2]. The hydrogenated amorphous-Si (a-Si:H) films and the microcrystalline-Si ( $\mu$ c-Si) films have been popularly utilized to fabricate the Si-based thin film solar cells. However, the a-Si:H films deposited using a plasma enhanced chemical vapor deposition (PECVD) system suffer from the light illumination induced degradation (Staebler-Wronski effect) [3]. This degradation phenomenon could be attributed to that when the a-Si:H thin film solar cells were illuminated by sunlight for a period time, a part of $\mathrm{Si}-\mathrm{H}$ bonds in the a-Si:H films were broken, and the resulting dangling bonds produced carrier quenching centers, which degraded the performances of the solar cells. In contrast, the $\mu \mathrm{c}-\mathrm{Si}$ films did not have this problem and were more suitable to be applied to construct the thin film solar cells. In this work, the laser-assisted plasma enhanced chemical vapor deposition (LAPECVD) system invented by our research group was used to directly deposit $\mu \mathrm{c}$-Si films without further annealing treatment [4-8]. The silane $\left(\mathrm{SiH}_{4}\right)$ reacting gas could be easily and efficiently decomposed into $\mathrm{Si}$ atoms under the combined action of the plasma and $\mathrm{CO}_{2}$ laser, due to the high absorption coefficient of $\mathrm{SiH}_{4}$ reacting gas at a wavelength of $\mathrm{CO}_{2}$ laser $(10.6 \mu \mathrm{m})$. Consequently, the high quality microcrystalline intrinsic $\mathrm{Si}(\mu \mathrm{c}-\mathrm{i}-\mathrm{Si})$ films could be deposited by the LAPECVD system at low temperature for the Si-based thin film solar cells. However, compared with the a-Si thin film solar cells, the open circuit voltage $\left(V_{o c}\right)$ and fill factor (FF) of the $\mu \mathrm{c}$-Si thin film solar cells were lower $[9,10]$. To overcome the above problem, the p-SiC film was deposited as the window layer to enhance the $V_{\mathrm{oc}}$ and FF. In addition, since the $\mathrm{SiC}$ is a wide bandgap material, the carrier recombination in the $\mathrm{SiC}$ layer is slower, which is beneficial to the improvement in the efficiency of resulting solar cells.

Since the quality of Si thin films played an important role in the Si-based thin film solar cells, in addition to the film deposition technique, many treatment technologies were 


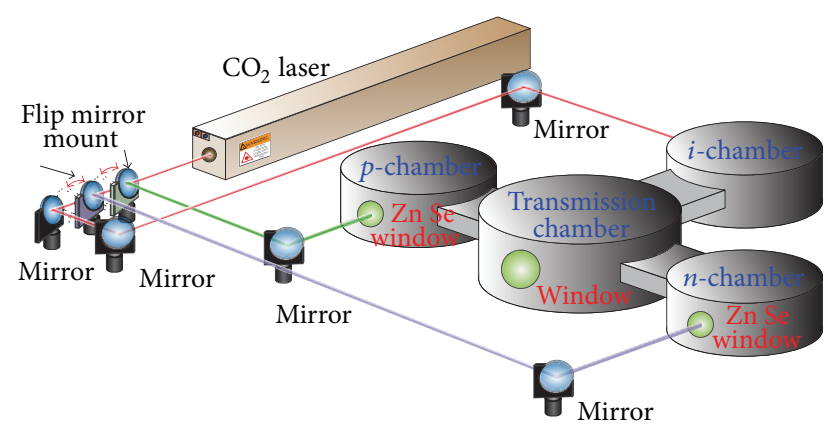

FIGURE 1: Schematic diagram of three-chamber LAPECVD system.

also utilized to passivate the dangling bonds in the Si thin films, such as hydrogen plasma treatment [11-13], $\mathrm{HNO}_{3}$ treatment [14], chemical HF treatment [15], wet-chemical treatment [16], and $\mathrm{Al}_{2} \mathrm{O}_{3}$ passivation [17]. In this work, at the deposited processes, to avoid the contamination between the films by the external environment, all the fabricated processes of the microcrystalline $\mathrm{p}-\mathrm{SiC} / \mathrm{i}-\mathrm{Si} / \mathrm{n}$-Si solar cells were kept in the vacuum environment. Consequently, among those treatment technologies, the hydrogen treatment technique was used to treat the $\mathrm{p}$-SiC layer surface for decreasing the dangling bonds and improving the performance of the microcrystalline $\mathrm{p}-\mathrm{SiC} / \mathrm{i}-\mathrm{Si} / \mathrm{n}-\mathrm{Si}$ thin film solar cells.

\section{Experiments}

Figure 1 shows the schematic configuration of the threechamber LAPECVD system used in the work. The three chambers were designed to prevent the dopants cross contamination during the deposition of the n-type, intrinsictype (i-type), and p-type Si-based films. To investigate the function of the laser assistance for the improvement in the properties of the deposited i-Si films, $150 \mathrm{~nm}$-thick i-Si films were deposited on glass substrates using a LAPECVD system with various assisting laser powers of $0,50,60,70$, and $80 \mathrm{~W}$. Meanwhile, the radio frequency (RF, $13.56 \mathrm{MHz}$ ) power, chamber pressure, flow rate of hydrogen-diluted $\mathrm{SiH}_{4}$ (5\%) reacting gas, and substrate temperature were set to be $20 \mathrm{~W}$, 0.6 torr, $60 \mathrm{sccm}$, and $250^{\circ} \mathrm{C}$, respectively. The bonding configuration and crystallization characteristics of the deposited i-Si films were analyzed using Fourier transform infrared (FTIR) spectrometry, micro-Raman scattering spectroscopy, and X-ray diffraction (XRD), respectively.

Figure 2 shows the schematic configuration of the $\mathrm{p}$ $\mathrm{SiC} / \mathrm{i}-\mathrm{Si} / \mathrm{n}-\mathrm{Si}$ thin films solar cells. A $25 \mathrm{~nm}$-thick p-SiC layer was deposited on the fluorine-doped tin oxide- (FTO-) coated glass substrate with texture structure using the LAPECVD system with assisting laser power of $80 \mathrm{~W}$. The reacting gases, hydrogen-diluted $\mathrm{SiH}_{4}(5 \%)$, methane $\left(\mathrm{CH}_{4}\right)$, and hydrogen-diluted diborane $\left(\mathrm{B}_{2} \mathrm{H}_{6}\right)(1 \%)$, were utilized as the $\mathrm{Si}, \mathrm{C}$, and p-type dopant sources, respectively. The corresponding flow rate was $70 \mathrm{sccm}, 25 \mathrm{sccm}$, and $4 \mathrm{sccm}$, respectively. The RF power, chamber pressure, and substrate temperature were kept at $20 \mathrm{~W}, 1.1$ torr, and $250^{\circ} \mathrm{C}$, respectively. The hole concentration and conductivity of the p-SiC

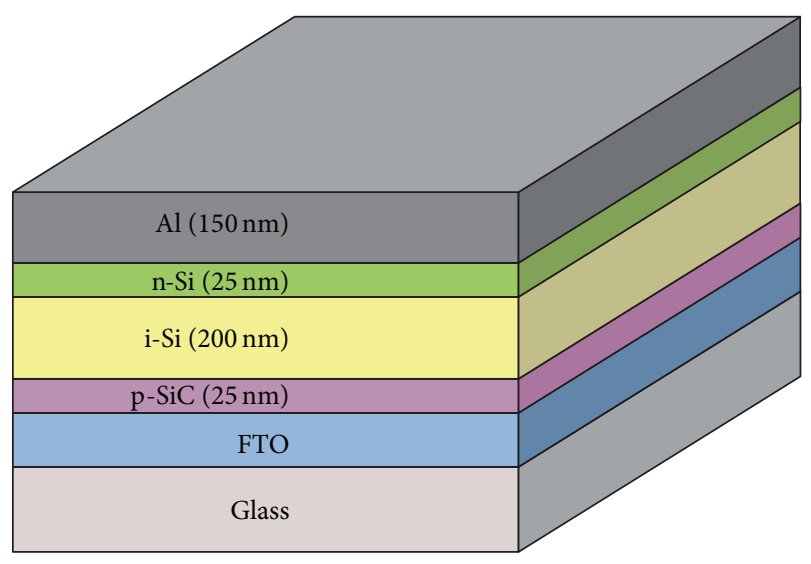

FIGURE 2: Schematic configuration of the $\mathrm{p}-\mathrm{SiC} / \mathrm{i}-\mathrm{Si} / \mathrm{n}-\mathrm{Si}$ thin film solar cells.

layer deposited with assisting laser power of $80 \mathrm{~W}$ were $4.06 \times$ $10^{17} \mathrm{~cm}^{-3}$ and $2.58 \times 10^{-2} \mu \mathrm{S} / \mathrm{cm}$, respectively. Prior to the deposition of the $\mathrm{i}-\mathrm{Si}$ absorption layer, the $\mathrm{p}-\mathrm{SiC}$ surface was passivated using hydrogen plasma treatment at RF power of $20 \mathrm{~W}$ for $25 \mathrm{~min}$. A $200 \mathrm{~nm}$-thick i-Si layer was immediately deposited on the p-SiC layer using the LAPECVD system with assisting laser power of $80 \mathrm{~W}$. The RF power, chamber pressure, flow rate of hydrogen-diluted $\mathrm{SiH}_{4}$ (5\%) reacting gas, and substrate temperature were kept at $20 \mathrm{~W}, 0.6$ torr, $60 \mathrm{sccm}$, and $250^{\circ} \mathrm{C}$, respectively. Subsequently, a $20 \mathrm{~nm}-$ thick n-Si layer was deposited, using the same equipment with assisting laser power of $80 \mathrm{~W}$, on the i-Si absorption layer. The hydrogen-diluted $\mathrm{SiH}_{4}(5 \%)$ and hydrogen-diluted phosphine $\left(\mathrm{PH}_{3}\right)(1 \%)$ reacting gases were used as the $\mathrm{Si}$ and n-type dopant sources, respectively. The corresponding flow rate was $40 \mathrm{sccm}$ and $10 \mathrm{sccm}$, respectively. The RF power, chamber pressure, and substrate temperature were kept at $60 \mathrm{~W}, 0.4$ torr, and $250^{\circ} \mathrm{C}$, respectively. The electron concentration and conductivity of the $\mathrm{n}$-Si layer deposited with assisting laser power of $80 \mathrm{~W}$ were $5.74 \times 10^{19} \mathrm{~cm}^{-3}$ and $8.75 \mu \mathrm{S} / \mathrm{cm}$, respectively. Finally, a $150 \mathrm{~nm}$-thick $\mathrm{Al}$ electrode was deposited on the $\mathrm{n}$-Si layer using the electron beam evaporator. The active area of the solar cell was $0.025 \mathrm{~cm}^{2}$. The $\mathrm{p}-\mathrm{SiC} / \mathrm{i}-\mathrm{Si} / \mathrm{n}-\mathrm{Si}$ thin film solar cells deposited without laser assistance were also fabricated for comparison. The hole concentration and conductivity of the $\mathrm{p}$-SiC layer deposited without laser assistance were $2.73 \times 10^{16} \mathrm{~cm}^{-3}$ and $3.45 \times 10^{-3} \mu \mathrm{S} / \mathrm{cm}$, respectively. The electron concentration and conductivity of the $\mathrm{n}$-Si layer deposited without laser assistance were $2.61 \times 10^{18} \mathrm{~cm}^{-3}$ and $5.26 \times 10^{-1} \mu \mathrm{S} / \mathrm{cm}$, respectively.

\section{Experimental Results and Discussion}

The bonding configurations of the i-Si films deposited with various assisting laser powers were carried out using a Fourier transformation infrared (FTIR) spectrometry. Figure 3 shows the absorption spectra $\alpha(\omega)$ of the deposited i-Si films, where $\alpha(\omega)$ was the absorption coefficient as a function of wavenumber $\omega$ of the light. In particular, the absorption 
spectrum $\alpha(\omega) / \omega$ of the i-Si films deposited with assisting laser power of $80 \mathrm{~W}$ was shown in the inset of Figure 3. All the measured spectra, after decomposition, exhibited two bands with peak positions of $2000 \mathrm{~cm}^{-1}$ and $2100 \mathrm{~cm}^{-1}$, which correspond to the stretching vibrations of $\mathrm{SiH}$ and $\mathrm{SiH}_{2}$, respectively. The microstructure factor $R$ was defined as $R=I_{2100} /\left(I_{2100}+I_{2000}\right)$, where $I_{2000}$ and $I_{2100}$ were the corresponding intensity of the two decomposed bands. The $R$ of the $\mathrm{i}$-Si films deposited with assisting laser power of $0,50,60,70$, and $80 \mathrm{~W}$ was $0.382,0.318,0.282,0.237$, and 0.221 , respectively. The $R$ value decreased with the assisting laser power. In other words, the intensity of the band corresponding to $\mathrm{SiH}_{2}$ in the deposited i-Si films decreased with the assisting laser power, which implied that the high quality i-Si films could be obtained using the LAPECVD system. The hydrogen concentration $\left(N_{\mathrm{H}}\right)$ of the i-Si films deposited with assisting laser power of $80 \mathrm{~W}$ was estimated by the equation shown below [18]:

$$
N_{\mathrm{H}}=A_{2000} \int \frac{\alpha_{2000}(\omega)}{\omega} d \omega+A_{2100} \int \frac{\alpha_{2100}(\omega)}{\omega} d \omega,
$$

where $A_{2000}$ and $A_{2100}$ are proportionality constants at wavenumber of $2000 \mathrm{~cm}^{-1}$ and $2100 \mathrm{~cm}^{-1}$ and equal $9.0 \times$ $10^{19} \mathrm{~cm}^{-2}$ and $2.2 \times 10^{20} \mathrm{~cm}^{-2}$, respectively, $\alpha_{2000}(\omega)$ and $\alpha_{2100}(\omega)$ are the absorption coefficients of the bands centered at wavenumber of $2000 \mathrm{~cm}^{-1}$ and $2100 \mathrm{~cm}^{-1}$, respectively, and $\omega$ is the frequency in $\mathrm{cm}^{-1}$. The hydrogen content $\left(C_{\mathrm{H}}\right)$ of the i-Si films deposited with and without laser assistance could be also estimated by the equation $N_{\mathrm{H}} / N_{\mathrm{Si}} \times 100 \%$, where $N_{\mathrm{Si}}$ of $5 \times 10^{22} \mathrm{~cm}^{-3}$ is the number density of crystal $\mathrm{Si}$ [19]. Figure 4 shows the hydrogen concentration and hydrogen content of the deposited $\mathrm{i}$-Si films as a function of the assisting laser power used in the film deposition. As shown in Figure 4, the $N_{\mathrm{H}}$ of $1.10 \times 10^{21} \mathrm{~cm}^{-3}$ and the $C_{\mathrm{H}}$ of $2.20 \%$ for the i-Si films deposited with assisting laser power of $80 \mathrm{~W}$ were smaller than the $N_{\mathrm{H}}$ of $5.98 \times 10^{21} \mathrm{~cm}^{-3}$ and the $C_{\mathrm{H}}$ of $11.96 \%$ for the i-Si films deposited without laser assistance. The $N_{\mathrm{H}}$ and $C_{\mathrm{H}}$ of the deposited i-Si films decreased with the laser power. It could be attributed to the fact that the $\mathrm{SiH}_{4}$ reacting gas could be efficiently decomposed into $\mathrm{Si}$ atoms by the combined action of plasma and $\mathrm{CO}_{2}$ laser and less hydrogen atom was left in the obtained microcrystalline i-Si films.

To further clarify the microstructure and the chemical bonding characteristics of the i-Si films deposited with various assisting laser powers, the micro-Raman scattering spectra were measured and the results are shown in Figure 5. As shown in Figure 5, the Raman peak of the i-Si films shifted from $482 \mathrm{~cm}^{-1}$ to $512 \mathrm{~cm}^{-1}$ as the assisting laser power increased from $0 \mathrm{~W}$ to $80 \mathrm{~W}$, indicating a gradual transformation from amorphous to crystalline Si. Therefore, these micro-Raman results verified that the $\mathrm{CO}_{2}$ laser-assisted deposition led to an enhancement in the crystallinity of the $\mathrm{i}$-Si films and the microcrystalline i-Si films were obtained when deposited with laser assistance of higher power.

The crystallinity of the i-Si films deposited with various assisting laser powers was also examined using X-ray diffraction (XRD) and the results are shown in Figure 6. In the XRD results, no diffraction peak could be found for
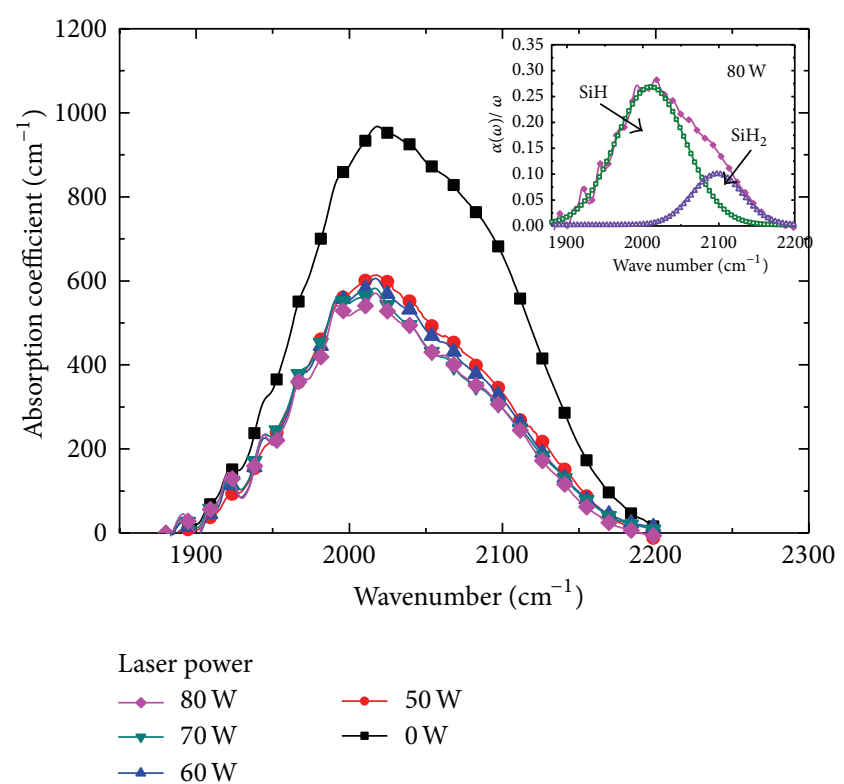

FIGURE 3: Absorption spectra $\alpha(\omega)$ of the i-Si films deposited with various assisting laser powers. The inset shows the absorption spectrum $\alpha(\omega) / \omega$ of the i-Si films with assisting laser power of $80 \mathrm{~W}$.

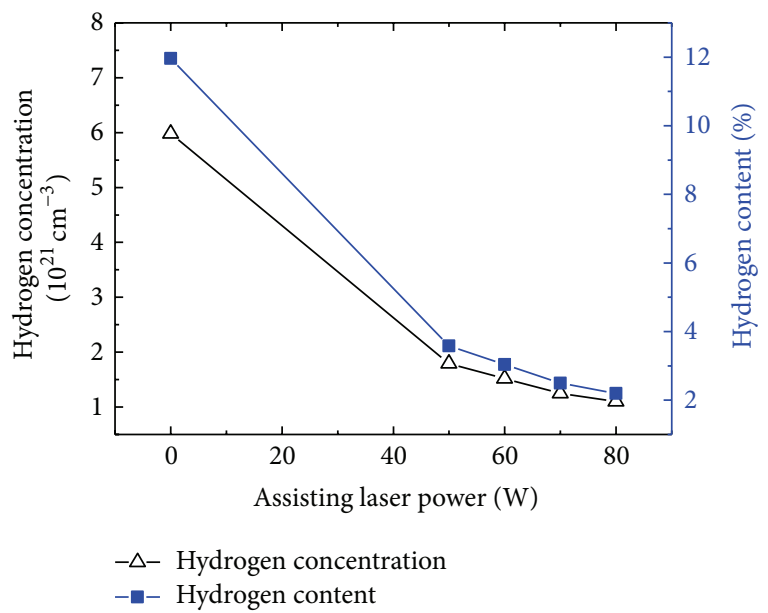

FIgURE 4: Hydrogen concentration $N_{\mathrm{H}}$ and hydrogen content $C_{\mathrm{H}}$ of the i-Si films deposited with various assisting laser powers.

the i-Si film deposited without laser assistance. On the contrary, for all of the i-Si films deposited with laser assistance, three main diffraction peaks at $2 \theta$ positions of $28.47^{\circ}, 47.34^{\circ}$, and $56.17^{\circ}$ were observed clearly, which correspond to the (111), (220), and (311) diffraction of the diamond-cubic Si, respectively. The above XRD results further confirmed that the microcrystalline $\mathrm{i}$-Si films could be directly deposited using LAPECVD system at substrate temperature of $250^{\circ} \mathrm{C}$.

Figure 7 shows the current density-voltage $(J-V)$ characteristics of the $\mathrm{p}-\mathrm{SiC} / \mathrm{i}-\mathrm{Si} / \mathrm{n}-\mathrm{Si}$ thin film solar cells deposited without and with $80 \mathrm{~W}$ laser assistance. The corresponding short-circuit current density $\left(J_{\mathrm{sc}}\right)$, open-circuit voltage $\left(V_{\mathrm{oc}}\right)$, fill factor $(\mathrm{FF})$, and power conversion efficiency $(\eta)$ were estimated and listed in the inset of Figure 7. The $J_{\mathrm{sc}}$ of 


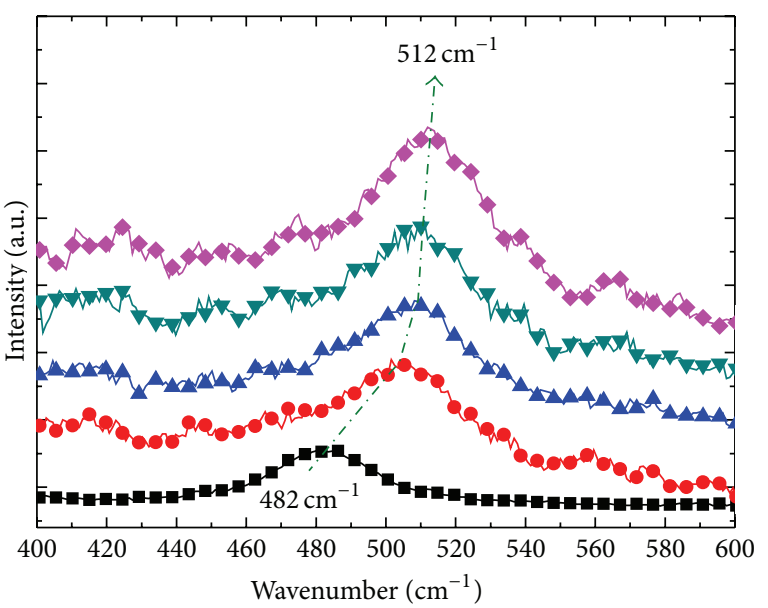

Laser power

$\rightarrow 80 \mathrm{~W} \rightarrow 50 \mathrm{~W}$

$\rightarrow 70 \mathrm{~W}$

$\leftarrow 60 \mathrm{~W}$

FIGURE 5: Micro-Raman scattering spectra of the i-Si films deposited with various assisting laser powers.

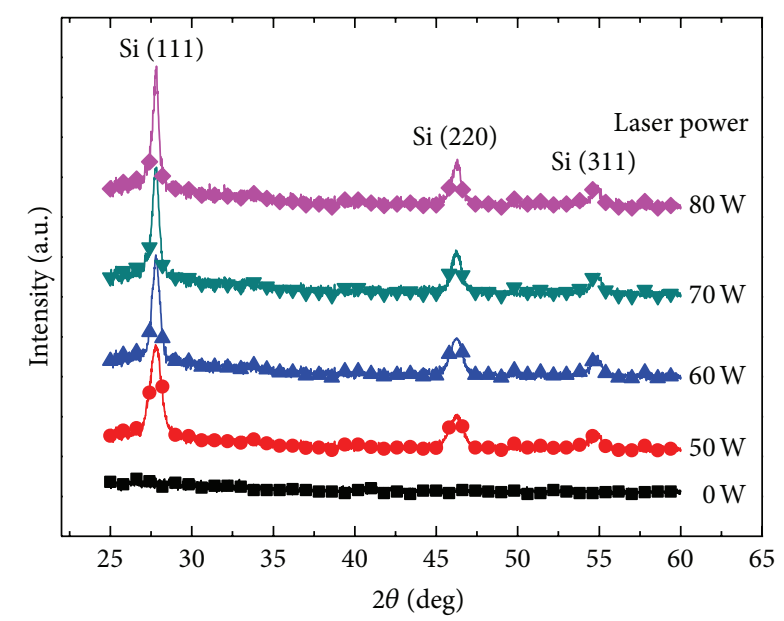

FIGURE 6: XRD spectra of the i-Si films deposited with various assisting laser powers.

the $\mathrm{p}-\mathrm{SiC} / \mathrm{i}-\mathrm{Si} / \mathrm{n}-\mathrm{Si}$ thin film solar cells with $80 \mathrm{~W}$ laser assistance was $18.16 \mathrm{~mA} / \mathrm{cm}^{2}$, much larger than the value of $14.38 \mathrm{~mA} / \mathrm{cm}^{2}$ for the cell without laser assistance. The increase in $J_{\mathrm{sc}}$ could be attributed to the enhancement of the crystallinity of the active layer i-Si film deposited with laser assistance. Besides, the electron and hole concentrations in the laser-assisted Si-based solar cells were higher than that in the non-laser-assisted Si-based solar cells. The high buildin electronic field could be increased with the high carrier concentration, which increased the separation velocity of the photo-generated electron-hole pairs in the active layer. Therefore, it could reduce the carrier recombination and increase the $J_{\mathrm{sc}}$ of the resulted solar cells with laser assistance. On the contrary, the $V_{\text {oc }}$ of the $\mathrm{p}-\mathrm{SiC} / \mathrm{i}-\mathrm{Si} / \mathrm{n}$-Si thin film solar cells decreased from $0.80 \mathrm{~V}$ to $0.75 \mathrm{~V}$ as the assisting laser

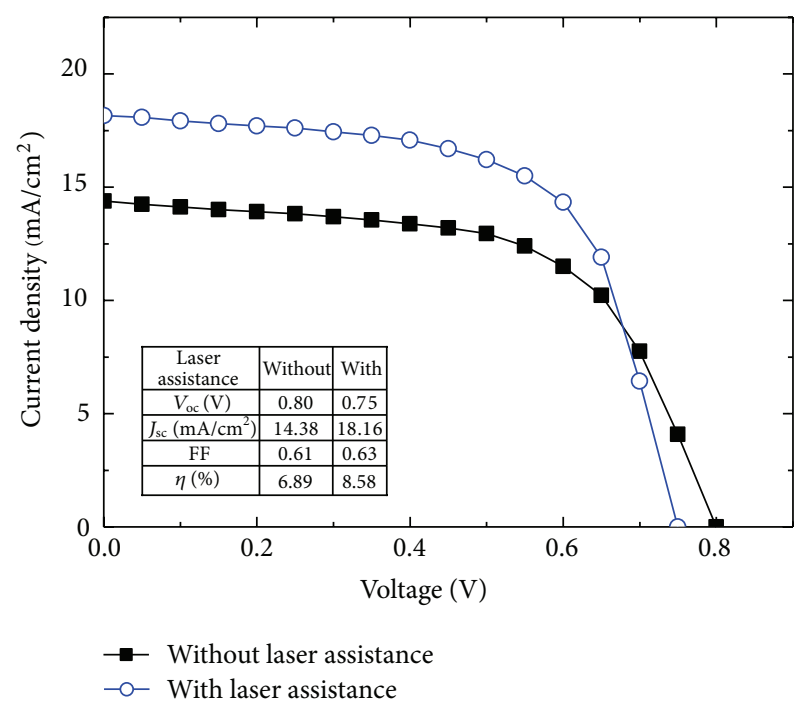

Figure 7: Current density-voltage characteristics of the p-SiC/i$\mathrm{Si} / \mathrm{n}$-Si thin film solar cells deposited without and with assisting laser power of $80 \mathrm{~W}$. The inset table shows the $V_{\mathrm{oc}}, J_{\mathrm{sc}}, \mathrm{FF}$, and $\eta$ of the $\mathrm{p}-\mathrm{SiC} / \mathrm{i}-\mathrm{Si} / \mathrm{n}$-Si thin film solar cells deposited without and with assisting laser power of $80 \mathrm{~W}$.

power used in the film deposition increased from $0 \mathrm{~W}$ to $80 \mathrm{~W}$. The reduction of the $V_{\text {oc }}$ for the laser-assisted Si-based solar cells was attributed to the crystallization variation of the i-Si absorption layer. The i-Si film deposited without laser assistance was amorphous, while the i-Si film deposited with laser assistance was microcrystalline. It is well known that the energy bandgap of the amorphous $\mathrm{Si}$ is larger than that of the microcrystalline $\mathrm{Si}$, which interprets the obtained variation of $V_{\mathrm{oc}}$. Furthermore, the $\mathrm{FF}$ of the $\mathrm{p}-\mathrm{SiC} / \mathrm{i}-\mathrm{Si} / \mathrm{n}-\mathrm{Si}$ thin film solar cells decreased when the i-Si layer was deposited under higher assisting laser power. This phenomenon was attributed mainly to the reduction of the $V_{\text {oc }}$. As shown in Figure 7, the power conversion efficiency of the $\mathrm{p}-\mathrm{SiC} / \mathrm{i}-\mathrm{Si} / \mathrm{n}-\mathrm{Si}$ thin film solar cells deposited with and without laser assistance was estimated to be $8.58 \%$ and $6.89 \%$, respectively. The significant improvement of the power conversion efficiency for the laserassisted Si-based solar cells was attributed to the fact that the laser-assisted i-Si absorption layer had lower hydrogen concentration and better crystallinity compared with the non-laser-assisted i-Si absorption layer.

\section{Conclusion}

In this work, the LAPECVD system was used to prepare the i-Si films as the active layers of solar cells. According to the FTIR measurement, the estimated hydrogen concentration of the deposited i-Si films decreased from $5.98 \times 10^{21} \mathrm{~cm}^{-3}$ to $1.10 \times 10^{21} \mathrm{~cm}^{-3}$ as the assisting laser power used during the film deposition increased from $0 \mathrm{~W}$ to $80 \mathrm{~W}$. The micro-Raman and XRD measurements demonstrated that the i-Si films deposited without and with laser assistance were amorphous and microcrystalline, respectively. In particular, deposited with $80 \mathrm{~W}$ laser assistance, the high quality i-Si 
films with low hydrogen content and microcrystalline structure were obtained.

The $\mathrm{p}-\mathrm{SiC} / \mathrm{i}-\mathrm{Si} / \mathrm{n}-\mathrm{Si}$ thin film solar cells with the active layer i-Si deposited without and with $80 \mathrm{~W}$ laser assistance were fabricated and investigated. The short-current density of the laser-assisted Si-based solar cells was larger than that of the cells without laser assistance. The improvement in conversion efficiency of the laser-assisted Si-based thin film solar cells was more than $22.5 \%$ compared with the solar cells without laser assistance.

\section{Conflict of Interests}

The authors declare that there is no conflict of interests regarding the publication of this paper.

\section{Acknowledgments}

The authors gratefully acknowledge the support from the Ministry of Science and Technology of Republic of China under Contract no. MOST 101-2628-E-006-017-MY3, no. MOST 103-3113-E-005-001 and Advanced Optoelectronic Technology Center and Research Center Energy Technology and Strategy of the National Cheng Kung University.

\section{References}

[1] D. Gerlach, R. G. Wilks, D. Wippler et al., "The silicon/zinc oxide interface in amorphous silicon-based thin-film solar cells: understanding an empirically optimized contact," Applied Physics Letters, vol. 103, no. 2, Article ID 023903, 2013.

[2] C. H. Hsu, Y. P. Lin, H. J. Hsu, and C. C. Tsai, "Enhanced spectral response by silicon nitride index matching layer in amorphous silicon thin-film solar cells," Journal of Non-Crystalline Solids, vol. 358, no. 17, pp. 2324-2326, 2012.

[3] D. L. Staebler and C. R. Wronski, "Reversible conductivity changes in discharge-produced amorphous Si," Applied Physics Letters, vol. 31, no. 4, pp. 292-294, 1977.

[4] C. T. Lee and C. H. Lin, "Si nanocrystals embedded in Si suboxide matrix grown by laser-assisted chemical vapor deposition at room temperature," Japanese Journal of Applied Physics, Part 1: Regular Papers and Short Notes and Review Papers, vol. 43, no. 5 A, pp. 2793-2794, 2004.

[5] C. T. Lee, C. H. Lin, T. H. Lee, and T. C. Tsai, "Photoluminescence degradation and passivation mechanisms of Si nanoclusters in silicon oxide matrix," Japanese Journal of Applied Physics, Part 1: Regular Papers and Short Notes and Review Papers, vol. 44, no. 6 A, pp. 4240-4244, 2005.

[6] C. T. Lee, J. H. Cheng, and H. Y. Lee, "Crystalline SiGe films grown on Si substrates using laser-assisted plasma-enhanced chemical vapor deposition at low temperature," Applied Physics Letters, vol. 91, no. 9, Article ID 091920, 2007.

[7] T. C. Tsai, L. Z. Yu, and C. T. Lee, "Electroluminescence emission of crystalline silicon nanoclusters grown at a low temperature," Nanotechnology, vol. 18, no. 27, Article ID 275707, 2007.

[8] C. T. Lee, Y. F. Chen, and C. H. Lin, "Phase-separated Si nanoclusters from Si oxide matrix grown by laser-assisted chemical vapor deposition," Nanotechnology, vol. 20, no. 2, Article ID 025702, 2009.
[9] B. R. Wu, D. S. Wuu, M. S. Wan, W. H. Huang, H. Y. Mao, and R. H. Horng, "Fabrication of nc-Si/c-Si solar cells using hot-wire chemical vapor deposition and laser annealing," Solar Energy Materials and Solar Cells, vol. 93, no. 6-7, pp. 993-995, 2009.

[10] A. V. Shah, J. Meier, E. Vallat-Sauvain et al., "Material and solar cell research in microcrystalline silicon," Solar Energy Materials and Solar Cells, vol. 78, no. 1-4, pp. 469-491, 2003.

[11] A. Descoeudres, L. Barraud, S. de Wolf et al., "Improved amorphous/crystalline silicon interface passivation by hydrogen plasma treatment," Applied Physics Letters, vol. 99, no. 12, Article ID 123506, 2011.

[12] A. Ulyashin and A. Sytchkova, "Hydrogen related phenomena at the ITO/a-Si:H/Si heterojunction solar cell interfaces," Physica Status Solidi A, vol. 210, no. 4, pp. 711-716, 2013.

[13] F. H. Wang, H. P. Chang, C. C. Tseng, C. C. Huang, and H. W. $\mathrm{Liu}$, "Influence of hydrogen plasma treatment on $\mathrm{Al}$-doped $\mathrm{ZnO}$ thin films for amorphous silicon thin film solar cells," Current Applied Physics, vol. 11, supplement 1, pp. S12-S16, 2011.

[14] K. Imamura, M. Takahashi, A. Asuha, Y. Hirayama, S. Imai, and H. Kobayashi, "Nitric acid oxidation of Si method at $120^{\circ} \mathrm{C}$ : $\mathrm{HNO}_{3}$ concentration dependence," Journal of Applied Physics, vol. 107, no. 5, Article ID 054503, 2010.

[15] J. H. Choi, S. C. Roh, J. D. Jung, and H. I. Seo, "Chemical HF treatment for rear surface passivation of crystalline silicon solar cells," Transactions on Electrical and Electronic Materials, vol. 14, no. 4, pp. 203-207, 2013.

[16] H. Angermann, J. Rappich, and C. Klimm, "Wet-chemical treatment and electronic interface properties of silicon solar cell substrates," Central European Journal of Physics, vol. 7, no. 2, pp. 363-370, 2009.

[17] M. Bhaisare, A. Misra, and A. Kottantharayil, "Aluminum oxide deposited by pulsed-DC reactive sputtering for crystalline silicon surface passivation," IEEE Journal of Photovoltaics, vol. 3, no. 3, pp. 930-935, 2013.

[18] A. A. Langford, M. L. Fleet, B. P. Nelson, W. A. Lanford, and N. Maley, "Infrared absorption strength and hydrogen content of hydrogenated amorphous silicon," Physical Review B, vol. 45, no. 23, pp. 13367-13377, 1992.

[19] M. H. Brodsky, M. Cardona, and J. J. Cuomo, "Infrared and Raman spectra of the silicon-hydrogen bonds in amorphous silicon prepared by glow discharge and sputtering," Physical Review B, vol. 16, no. 8, pp. 3556-3571, 1977. 

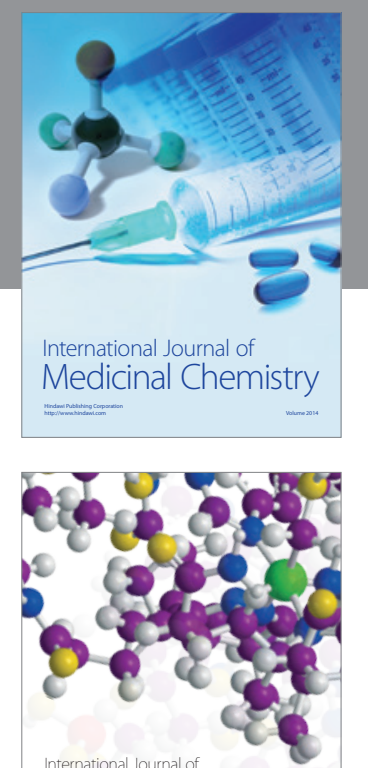

\section{Carbohydrate} Chemistry

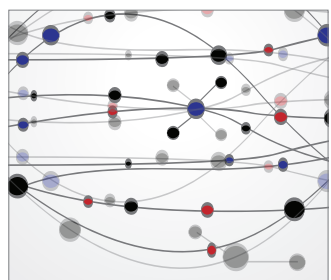

The Scientific World Journal
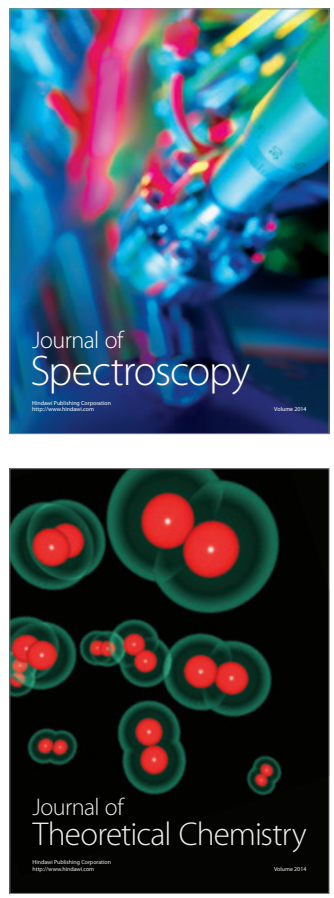
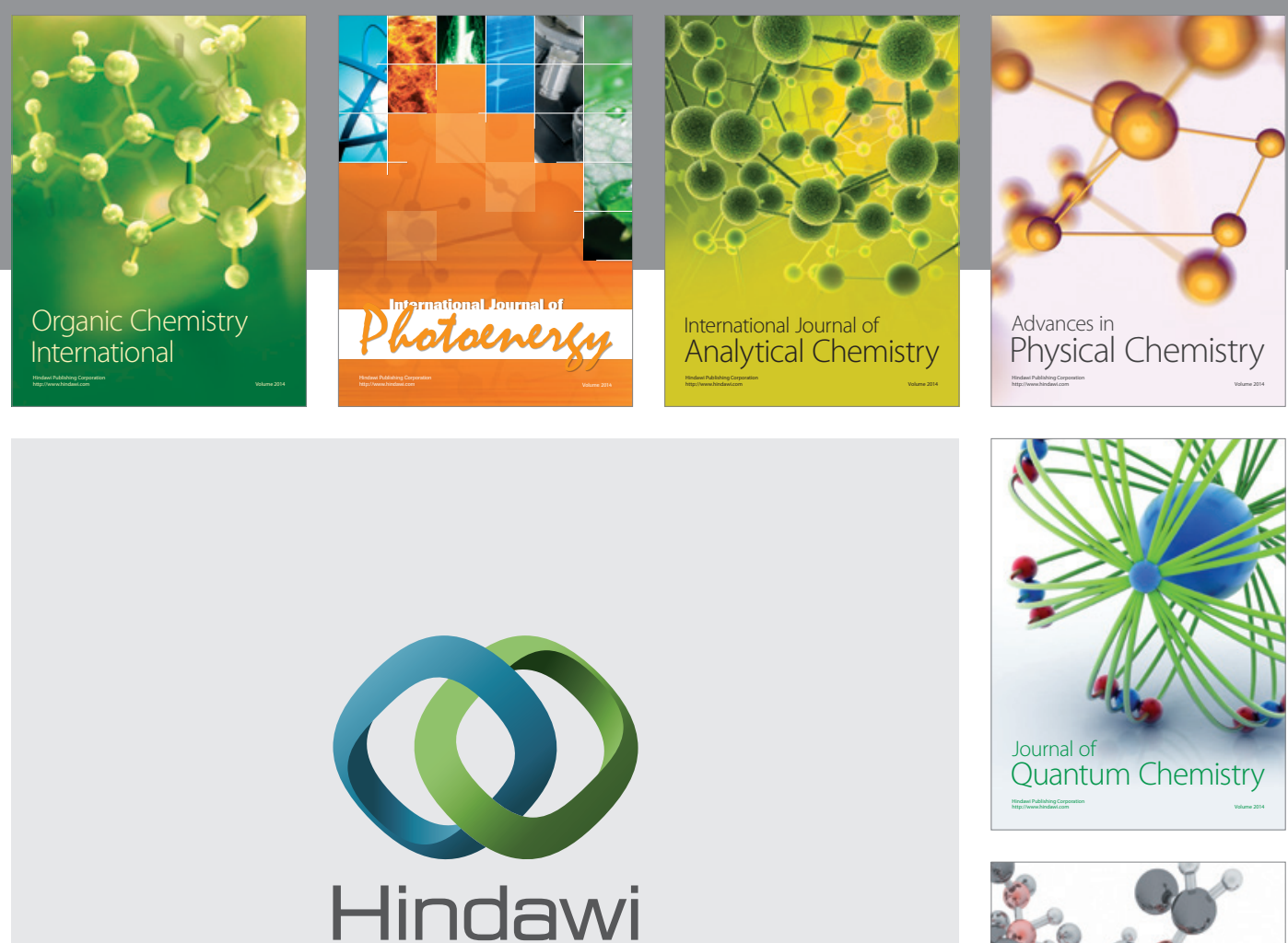

Submit your manuscripts at

http://www.hindawi.com

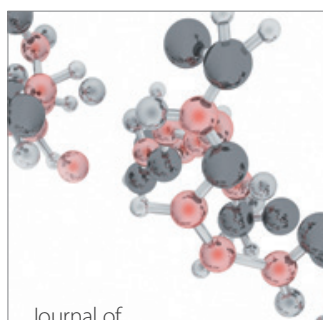

Analytical Methods

in Chemistry

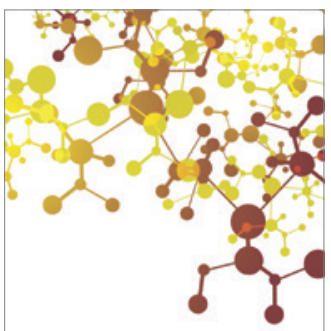

Journal of

Applied Chemistry

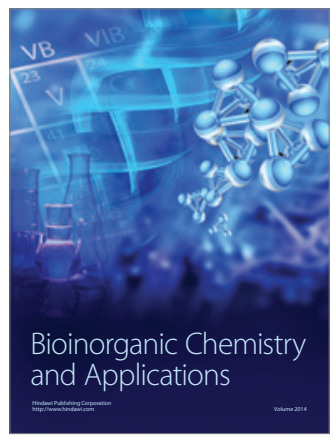

Inorganic Chemistry
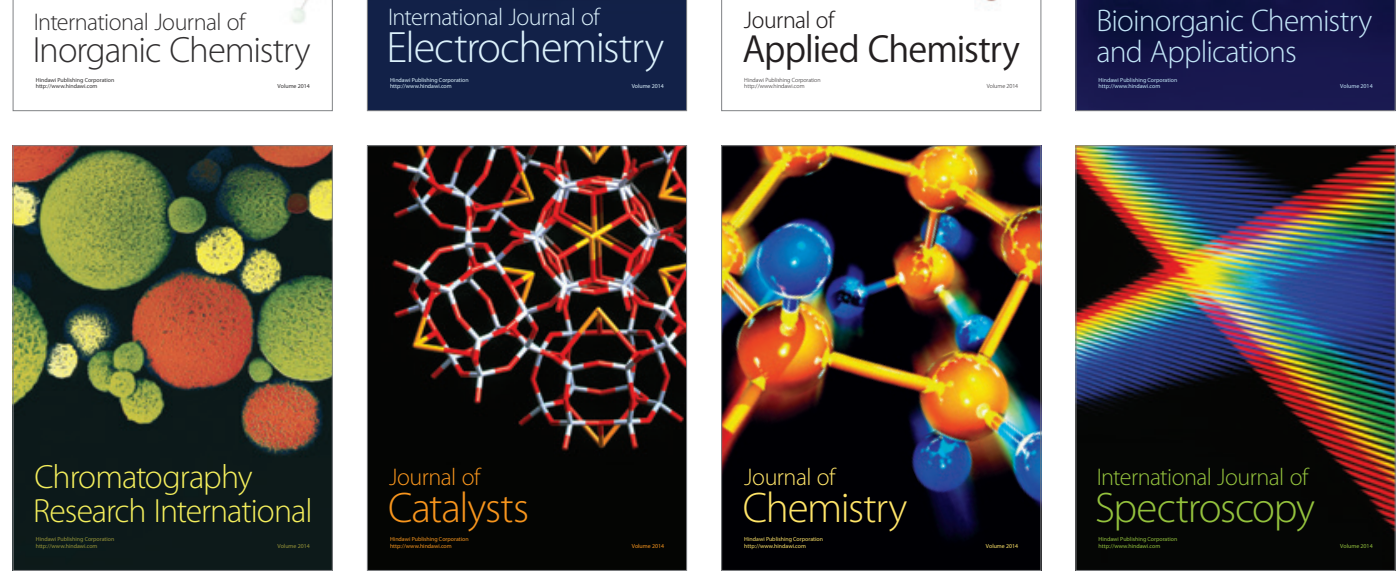